\title{
New managerialism in the academy: Gender bias and precarity
}

\author{
Finnborg S. Steinpórsdóttir ${ }^{1}$ (D) | Thomas Brorsen Smidt ${ }^{1}$ (D) | \\ Gyða M. Pétursdóttir ${ }^{1}$ (D) | Porgerður Einarsdóttir ${ }^{1}$ (D) | Nicky Le Feuvre ${ }^{2}$ (D)
}

${ }^{1}$ Faculty of Political Science, University of Iceland

${ }^{2}$ Institut des sciences sociales, University of Lausanne

Correspondence

Finnborg Salome Steinbórsdóttir, Faculty of Political Science, University of Iceland, Sæmundargata 2, 101 Reykjavík, Iceland. Email: finnborg@hi.is
In the era of global competition, academic institutions are increasingly being managed as efficient organizations where early career academics are the most vulnerable group in the academic hierarchy. We use gender budgeting to deconstruct the financial and managerial processes and procedures in a selected academic institution in Iceland. Drawing on multiple data collection methods, we argue that new managerialism enhances the precarious position of early career academics, especially women and those in the more feminized fields. Furthermore, we show that the system's bias in favour of so-called hard science generates gendered consequences for early career academics. We demonstrate this structural gender bias in each of the first three stages of an academic career: $\mathrm{PhD}$, postdoc and other temporary positions, and assistant professorship. By highlighting the gendered consequences of new managerialism, we want to direct attention to the need to include a gender perspective in the budgeting and all the decision-making processes in academic institutions.

\section{KEYWORDS}

academics, gender budgeting, higher education, performance indicators, precarity

\section{1 | INTRODUCTION}

In the current era of global competition (Marginson \& Van der Wende, 2007) and the ensuing neoliberalization of higher education in many national contexts (e.g., Ginsberg, 2011; Newfield, 2008; Torres \& Schugurensky, 2002; Walsh, 2013), academic institutions are increasingly competing for international recognition with excellence as one of the main qualifiers (Borum \& Hansen, 2000). This has enabled the marketization of higher education, with 
academic institutions increasingly introducing private sector financial and managerial techniques and ideologies, often referred to as new managerialism (Deem \& Brehony, 2007; Deem, Hillyard, \& Reed, 2007). Academic institutions are increasingly required to monitor their efficiency, productivity and rankings (Barry, Berg, \& Chandler, 2012; Butler \& Spoelstra, 2014; Chandler, Barry, \& Berg, 2004) through performance indicators that are represented as objective and gender neutral (Lynch, 2010). Part of the marketization process of higher education involves a focus on ever-increasing knowledge production (Olssen \& Peters, 2010). For example, there is an intensified emphasis on producing ever-increasing numbers of $\mathrm{PhD}$ graduates in Europe (Steinbórsdóttir, Heijstra, Einarsdóttir, \& Pétursdóttir, 2016), despite signs that tenured academic positions are being replaced by temporary positions in recent years (Jongbloed, 2012). This is part of a more general precarization of higher education. In fact, Gill (2009) goes so far as to say that 'precariousness is one of the defining experiences of contemporary academic life' (p. 232). There are gendered aspects to this phenomenon.

In this article, we use gender budgeting as a lens to deconstruct the financial and managerial processes and procedures at work within a specific academic institution, in order to shed light on how new managerialism encourages precarity and sustains gender inequality in academia. Originally emerging from Australian feminist practices in the mid-1980s (Sharp \& Broomhill, 2002), gender budgeting aims to challenge gendered practices within gendered institutions (Acker, 1992). It consists of integrating gender perspectives into the budgeting processes in order to promote and facilitate gender equality (Addabbo, Gunluk-Senesen, \& O'Hagan, 2015; O'Hagan, 2016; Quinn, 2009). Without addressing unbalanced power relations, such as the gendered division of labour, an approach that ignores gender is likely to reproduce bias in decision-making procedures and processes, which results in a gendered distribution of resources (Elson, 1999). In academia, gendered power relations are visible in horizontal and vertical gender segregation patterns. Women are more likely to occupy the most precarious academic positions, while men dominate the more senior and secure ones (European Commission, 2016). Furthermore, a gendered division of labour exists with women and men in education and working in different fields, for example, Science, Technical, Engineering and Mathematics (STEM) is usually a male-dominated field, whereas Social Sciences and the Humanities (SSH) is a more feminized field (European Commission, 2016). Moreover, there is a long-standing association between STEM, the so-called hard sciences and masculinity (Francis et al., 2017; Pronin, Steele, \& Ross, 2004; Schiebinger, 1999). The culturally masculine fields are considered to be of higher value, hence more respected, than the more feminized fields. This implicit hierarchy can lead to bias in favour of STEM fields in the financial and managerial options of academic institutions (Steinpórsdóttir, Heijstra, \& Einarsdóttir, 2017).

In this article, we assess the gendered consequences of new managerialism on early career academics from two academic fields: the School of Social Sciences (SSH) and the School of Engineering and Natural Sciences (STEM) within a selected academic institution in Iceland (hereafter the University). The setting is particularly meaningful in this research context. The Icelandic academic system has undergone similar developments to those observed in other countries with an increased emphasis on managerialism within research and innovation closely connected to the goal of economic growth (Jóhannesson, 2013). However, a recent comparison of seven European academic and scientific institutions indicates that this particular university has gone much further than most of its counterparts in its efforts to operationalize new managerial principles in the pursuit of excellence (Steinpórsdóttir et al., 2016). We believe that the context of this Icelandic academic institution can facilitate our understanding of the broader international phenomenon of new managerialism in academia.

We argue that the emphasis on new managerialism reinforces the precarious positions of early career academics, especially women and those in the more feminized fields of study. We show that the system's bias in favour of the culturally masculine, or so-called hard sciences, impacts early career academics disproportionately. In short, STEM departments are able to provide more advantageous positions and better working conditions for their early career academics, who are mostly men, than the more feminized SSH school. Even though women in STEM are outnumbered and in a subordinate position within their field, the gender-biased status of their culturally masculine field allows them to enjoy many of its privileges, such as higher appraisal of their research output, greater access to research funding, lower student-teacher ratios and less academic housework (Heijstra, Einarsdóttir, Pétursdóttir, \& Steinpórsdóttir, 2017; 
Heijstra, Steinpórsdóttir, \& Einarsdóttir, 2017). We demonstrate this structural gender bias at each of the first three stages of an academic career: $\mathrm{PhD}$, postdoc and other temporary positions, and assistant professorship.

By highlighting how new managerialism produces a gendered structural bias, we want to draw attention to the need to include a gender perspective in all academic decision-making processes, in order to transform unequal gender structures and promote gender equality. In order to do so, we address the following research questions: Do the financial and managerial procedures and processes of academic institutions have different consequences for SSH and STEM and, therefore, unintended, gendered consequences for precarious knowledge workers? If so, how does this manifest itself? Before addressing these questions directly, we discuss new managerialism and precarity in academia.

\section{I NEW MANAGERIALISM AND GENDERED ACADEMIA}

The idea of a world-class university and the aim of national governments to have their universities well-placed in international rankings have inspired higher education policies worldwide. Higher education institutions of various types and sizes participate in this competition, even though the comparison is usually based on a supposedly universal model of academic institutions (Paradeise \& Thoenig, 2015). This has enabled the marketization of higher education in Europe, a process of reorganization that started in the 1980 s, albeit with wide variations among countries (Paradeise \& Thoenig, 2015). As such, higher education is increasingly defined through a management lens. New managerialism is tied to the ideology of neoliberalism (Lynch, 2014) and can be defined as 'a philosophy in which the existence and operation of a market are valued in themselves [...] and where the operation of a market [...] is seen as an ethic in itself' (Treanor, 2005). Neoliberalism, therefore, does not mean that academic institutions are autonomous and free, but rather, that they are compelled to conform to the norms of the market (Keisu \& Carbin, 2014; Larner, 2000). This trend is also described as neoliberal market governance (Keisu \& Carbin, 2014), the McUniversity (Parker \& Jary, 1995), the corporate university (Donoghue, 2008) or academic capitalism (Slaughter \& Rhoades, 2004).

In this context, new managerial instruments have been elaborated as a means of allocating resources both at national and institutional levels with a view to maximizing efficiency. At the national level, governments increasingly rely on performance indicators, incentive mechanisms and a series of evaluation procedures to control the allocation of resources (Paradeise \& Thoenig, 2015). Likewise, in the name of efficiency, productivity and excellence, academic institutions are increasingly being run like corporations (Barry et al., 2012; Butler \& Spoelstra, 2014; Chandler et al., 2004; Farnham, 1999; Gouthro, 2002; Lynch, 2006; O'Connor, 2014; Rothe et al., 2008; Välimaa, 2012). Gender is usually not understood as a significant issue in the case of financial and managerial procedures that are presented as 'rational, efficient, accountable and giving value for money' (Lynch, 2010, p. 55) in reaching the goal of academic excellence.

However, academic institutions are gendered institutions (Acker, 1992). This is an outcome of long-standing inequality regimes in higher education, systems of organization, control and promotion that are more favourable to particular classes of men than to women (Acker, 2006). Many studies provide examples of the different manifestations of gendering within academic institutions, including the hiring and promotion processes (e.g., Van den Brink \& Benschop, 2011) and the so-called Matilda effect that leads to the systematic undervaluing of women's academic endeavours (e.g., Knobloch-Westerwick, Glynn, \& Huge, 2013; Rossiter, 1993). Furthermore, research shows that the evaluation of academic work is fraught with bias and has varying consequences for different academic fields. The monitoring of performance tends to privilege research activities by focusing on publication rates, journal rankings, citation indexes and funding success rates (Butler \& Spoelstra, 2014; Steinpórsdóttir et al., 2017; Svensson, Spoelstra, Pedersen, \& Schreven, 2010), whilst undervaluing teaching and other important tasks, such as student supervision, administration and other activities that could be regarded as academic housework (Heijstra, Steinpórsdóttir, et al., 2017; Lynch, 2006). As described in more detail in the context section, these performance measurements tend to advantage the male-dominated STEM fields as compared to the more feminized SSH fields (Steinpórsdóttir et al., 2017). 
Performance indicators specifically encourage a self-monitoring process in which academics are encouraged to view themselves as individual subjects who are responsible not only for their own production levels, but also for the reputation of their home institution (Deem et al., 2007). The evaluation system may include penalties for under-performance, including lower salaries, lost perks or even redundancy (Berg, Huijbens, \& Larsen, 2016; Steinpórsdóttir et al., 2017). Academic neoliberalism produces a feeling of growing precariousness among academics, who are made responsible for their own wellbeing (Keisu \& Carbin, 2014), even though they have little or no control over the wider processes that contribute to their success or failure (Berg et al., 2016).

\section{3 | PRECARIOUS WORK}

Precarious work may be broadly defined as 'employment that is uncertain, unpredictable, and risky from the point of view of the worker' (Kalleberg, 2009, p. 2). While job precarity is not new, it is generally agreed that it started to expand in the late 1970s, when globalization escalated economic integration and competition (Kalleberg, 2009), resulting in macro-level shifts from mass production to a flexible form of organization that focused on achieving excellence in manufacturing, which eventually 'brought the market [...] directly inside the firm' (Duguay, Laundry, \& Pasin, 1997, p. 1169). Under this new model of production, the idea of flexible labour replaced the notions of corporation and long-term interests (Duguay et al., 1997) between workers and their employer, in a way that served primarily to fulfil the needs of employers and capital (Fudge \& Owens, 2006).

It is now widely recognized that these neoliberal principles of organization have also found their way into the realm of academic employment (e.g., Ginsberg, 2011; Newfield, 2008; Torres \& Schugurensky, 2002; Walsh, 2013). The market of knowledge production is characterized by flexibility (Ward, 2012), with academic institutions increasingly employing academics on casual or fixed-term contracts in order to reduce costs and exercise more direct control over the content of their work (Lynch, 2014), leading to an increasing number of academics who experience their profession as precarious.

Early career academics have to face a new reality in which 'the pace of scientific production is accelerating within a context of strong competition for scant fixed-term positions' (Fusulier, del Rio Carral, \& Murgia, 2013, p. 1). The precarious nature of prolonged, non-tenured positions and the prevalence of part-time jobs has wide-ranging consequences. Despite reporting relatively high levels of job satisfaction, knowledge workers in precarious positions worry disproportionally about their income, benefits and long-term job security (Kramer, Gloeckner, \& Jacoby, 2014; Leslie \& Gappa, 2002; Valadez \& Anthony, 2001). According to Adamowicz (2007), the precarious situation of academics also results in a decreased ability to take part in institutional governance. This is coupled with the observation that part-time academics without permanent contracts are rarely offered the same resources and support as their fulltime and tenured counterparts (Kezar, Maxey, \& Eaton, 2014).

Precarious work lives also have consequences for teaching and workload. Contingent faculty members often spend proportionally more time teaching than their tenured counterparts, yet are much less accessible to students because of their higher workloads (Schuster, 2003). In some national contexts, they are also more likely to teach the big introductory courses (Schuster \& Finkelstein, 2006), leading Klentzin and Bucci (2012) to name them 'the workhorses of higher education' (p. 101).

\section{I MATERIALLY GROUNDED RESEARCH}

The gendered nature of new managerialism in academia and its connection to precarious work has so far been largely overlooked in the literature. Recently, Ivancheva (2015) has argued that the academy is raising an 'army of workers' (p. 39), who encounter shorter, lower paid and more hyper-flexible contracts (i.e., precarity). However, this account is not particularly gendered. Lipton (2015) has argued that the 'pervasiveness in higher education of gendered precarity [...] is a product of ongoing post-industrial neoliberal economic reform' (p. 64). While this account provides an analysis 
of precarity and new managerialism from a gendered perspective, it is mostly theoretical in nature. By looking at new managerialism and precarity through a gender budgeting lens, and by rooting our conclusions solidly in the results of an empirical study, we hope to create a more materially grounded analysis of the topic at hand. Before turning to the findings of our research project, we elaborate on the context of the research and on the evaluation system utilized at the University.

\section{5 | PERFORMANCE MEASUREMENTS AND IMPACT ON ACADEMICS}

Since 2006, the University has been putting great effort into reaching a top position in the global academic rankings. Different reorganization projects have taken place and changes can be traced back to the late 1980s (Einarsdóttir, 1998). At the University, as at other public universities in Iceland, academics are evaluated according to a system elaborated specifically for public higher education institutions. According to this system, points are awarded to individual academics on the basis of their performance, in terms of research, teaching, administration and service to the community. At the University, these performance measurements are directly related to access to a wide range of resources and have a significant impact on academic careers, in terms of promotion opportunities, salaries, productivity bonuses, sabbaticals and the internal funding mechanisms (Steinpórsdóttir et al., 2017).

The evaluation of research is mostly based on biblio-metric indicators, using the Thomas Reuters/ISI Web of Science List (ISI) and ERIH databases. On a range from 0 to 100 points, articles in peer-reviewed journals, but also books and book chapters, are rewarded according to the relative prestige of their publishers/journals. In addition, since 2010, the introduction of special research points, referred to as 'major points', has increased the focus on research-related practices. Major points are only rewarded for 'excellent' publications in high impact journals, books and chapters from 'prestigious' publishing houses and for patents (10-100 major points). Publishing in the journals, which the University refers to as 'superior journals', such as Nature, Science, Cell or the New England Journal of Medicine, enables a scholar to receive additional points (20 for first author and 10 for co-authors). However, all these superior journals are journals that mostly publish work from STEM and health sciences.

Furthermore, academics are assigned points for other tasks, such as teaching (a standard 10 points annually for a full-time position, and the number of students and the level of the course do not impact the points), supervision of postgraduate students (2-10 points) and obtaining external research funding. The higher the endowment, the more points are awarded (0-20 points), with funding received through highly competitive international bids (such as the European Union (EU)) generating twice as many points than other grants (Evaluation System for Public Higher Education Institutions, 2013). As argued previously (Steinpórsdóttir et al., 2017), these performance indicators are presented as objective and gender neutral. In reality, they fail to recognize the gendered structure of academic institutions and are more favourable to research and teaching in the male-dominated STEM fields than in the more feminized SSH domains.

On recruitment at the University, academics are evaluated in accordance with the evaluation system and the accumulated number of points to determine their pay grade. Thereafter, they provide an annual performance report, detailing the work carried out over the previous year. All members of academic staff are required to obtain at least 10 points in addition to those awarded for teaching. On the basis of this performance report, the pay levels of academics are revised according to the total number of points recognized and rewarded. Those academics whose performance is above the annual publications threshold are rewarded with a so-called productivity bonus. The level of bonus is adjusted according to the number of points obtained. Thus, the most 'successful' researchers are more financially rewarded than others (Steinpórsdóttir et al., 2017). Promotions at the University are also based on the points system. Assistant and associate professors, as well as certain categories of researcher, are able to apply for promotion once a year. To be eligible for promotion to an associate professorship, assistant professors have to have a minimum of 20 points for teaching and 130 points for research, including at least 80 'major points'. The 'major points' thus play a central role in the academic career structure. Those assistant professors who fail to accumulate the required number of 
'major points' within the first five years of their academic career could lose their position at the University (Regulation no. 263/2010). Before addressing the unintended gendered consequences of these managerial procedures for the career opportunities and working conditions of precarious knowledge workers, we will discuss the data and methods.

\section{I DATA AND METHODS}

With the analytical tools of gender budgeting, we take a step back from the daily working of the University and pay attention to the structural effects of these apparently objective and transparent evaluation procedures. This is inspired by the analytical framework established by Bacchi $(2009,2012)$. By focusing on norms and standards that govern academic institutions, we are able to shed a light on how limits and exclusions are practised (Bacchi, 2012). In this article, we draw on empirical data collected as part of the GARCIA research project that was supported by the 7th Framework Programme of the European Union. ${ }^{1}$ The project is concerned with gender equality in higher education and research organizations, with a special focus on early career academics. The GARCIA research project project used multiple data collection methods, including secondary statistical analysis, document analysis, fact-finding and semi-structured interviews. The secondary data includes policy reports and internal documents, such as policy statements, annual reports, agreements, performance indicators, job descriptions, appointment reports and information about research grants. The quantitative data covers student numbers, tenured academic staff, other staff employed on non-tenured and temporary contracts, and appointment reports from 2010 to 2014 obtained from the University's website and directly from the central administration. We also obtained data on the publication output of the staff in 2013, the length of the PhD programmes, the number of PhD grants awarded and the number of research grants obtained by members of the University at the international, national and institutional level.

We carried out five fact-finding interviews with key players from the University central administration, four men and one woman, as well as 32 semi-structured interviews with 20 female and 12 male academics in the early stages of their careers. All the academics are currently or were formerly employed at the University, as assistant professors, postdocs and sessional lecturers in both STEM and SSH fields. The interviews were conducted between August 2014 and May 2015 and lasted between 40 and 75 minutes. They were digitally recorded, transcribed and analysed using the Atlas.ti version 1.0.2(68) research software. We identified and selected core categories and systematically carried out a thematic content analysis. The core categories identified were job security, time management, personal finances and workloads. In the following section, the term key player refers to a member of the University central administration, whereas we refer to the early career academics by gender, their position and academic field.

\section{7 | FINDINGS}

The findings reveal that the financial and managerial procedures and processes create a structural gender bias that disproportionately impacts early career academics in STEM and SSH. The STEM disciplines are able to provide more advantageous positions and working conditions for precarious knowledge workers than are the SSH disciplines. In the male-dominated STEM field, men are in a clear majority (75 per cent), producing an environment that is 'culturally masculine', whereas SSH is more feminized (55 per cent men). The degree to which early career academics are faced with precarious employment and working conditions clearly depends on the gendered disciplinary field they work in. We will demonstrate this gendered structural bias in each of the first three stages of an academic career.

\section{1 | A gendered funding gap for PhD candidates}

A recent assessment of the health problems experienced by Belgian $\mathrm{PhD}$ students found that the prevalence of mental health issues is higher among this group than in the highly educated population in general (Levecque, Anseel, Beuckelaer, Heyden, \& Gisle, 2017). In fact, half of the PhD students experience psychological distress, with work 
and organizational contexts being significant predictors of mental health problems. Compared to assistant lecturers, 'PhD students employed through project funding and those not knowing their funding resources showed significantly more psychological distress' (p. 875).

The number of $\mathrm{PhD}$ graduates is one of the key performance indicators used to monitor research progress at the University (University of Iceland, 2006, 2011, 2016). In line with this goal, the two schools both have large numbers of PhDs: 131 in STEM and 91 in SSH. In line with the contrasting gender composition of these fields, men make up a majority of $\mathrm{PhD}$ candidates (58 per cent) and PhD graduates (61 per cent) in STEM, whereas women are the majority of PhD candidates (72 per cent) and PhD graduates (75 per cent) in the SSH. At the University, preparing a PhD can either be funded through a research grant programme ('funded'), paid with funding obtained by the supervisor ('paid') or not funded at all ('unpaid'). Thus, not all PhD candidates experience the same employment status or degree of precariousness. As the interviews with key players reveal, the STEM department is able to offer higher levels of funding or payment to its $\mathrm{PhD}$ candidates, whereas those in SSH more often have to provide for themselves, usually as sessional lecturers or with student loans. $\mathrm{PhD}$ candidates can receive a salary if their supervisors have received external grants, from international competitive funds, for example. In addition, $\mathrm{PhD}$ candidates can apply for external and internal doctoral grants. The University awards doctoral grants annually. In the period 2010-2013, the STEM department received 2.2-3.3 more doctoral grants than the SSH department (University of Iceland, n.d.-f).

Funding has a clear impact on the duration of the $\mathrm{PhD}$, which is longer for SSH candidates than for their STEM counterparts. Of the PhDs that graduated between 2010 and 2013, six out of ten STEM candidates finished their $\mathrm{PhD}$ within five years as compared to two out of ten SSH candidates. Furthermore, the duration of the PhD is longer for women than for men in both schools. In STEM, 46 per cent of women finished their PhDs within five years as compared to 63 per cent of their male counterparts (University of Iceland, n.d.-b). In SSH, 17 per cent of women finished their PhD within five years as compared to 22 per cent of the men (University of Iceland, n.d.-b).

\section{2 | A doctorate: Privilege and precarity}

By the end of their doctoral studies, the STEM and SSH PhDs do not have the same career opportunities, either within or outside the University. Despite this, the University continues to put great emphasis on increasing the number of PhD graduates (University of Iceland, 2006, 2011, 2016), as is apparent in the policy statement for 2016-2021, where the University aims to: 'promote the continuation of a graduation rate of 70 doctoral students per year' (University of Iceland, 2016, p. 10). Iceland is a small country with few academic institutions, which means that job opportunities for academics are limited. Between 1 January 2010 and 31 December 2012, the University advertised 24 assistant professor positions in SSH and 26 in STEM. The job advertisements in SSH were written in Icelandic, while in STEM they were also published in English. The prevailing discourse seems to underline the importance of hiring candidates from non-Icelandic universities. That is to say, mobility is valued in prospective candidates. However, appointment reports indicate that there is a preference for Icelandic candidates in SSH. Also, looking at the hiring procedures from 2010 to 2013, the majority of successful candidates in both STEM and SSH had an Icelandic name (Einarsdóttir et al., 2015). This means that PhD graduates are in very stiff competition for the very few academic job opportunities, and thus chances of obtaining a position after the end of a PhD programme from the University are limited. A key player interviewed reflected on this particular problem:

I like to think that the business community will gradually want PhD educated staff. I like to think that. In reality, we have nothing to do with all these people within the academic system, that is my opinion.

However, in Iceland, STEM graduates are more likely than SSH graduates to find employment opportunities in the private sector.

There are some postdoc and researcher positions that are temporary and often dependent on external funding. As the key players revealed, these positions are very rare in SSH, but more common in STEM. Even though STEM $\mathrm{PhD}$ holders might be able to secure a funded postdoc position, retaining such a position and being able to secure 
adequate external funding can put these postdocs in a precarious situation. As a woman currently in a STEM postdoc position said:

I have to apply for funds constantly... I've made seven applications in the four years I've been here, and some of them take a month to write if I want to do it properly ... And if I want to qualify for a permanent position ... I need to do this, but at the same time this means I don't publish enough, so I will actually never reach the level where I become interesting [as an applicant].

The paradox here is, of course, that the postdoc position is meant to offer an opportunity for postdocs to write up their research, yet retaining one's position and acquiring additional funding is time-consuming. These conflicting demands on their time mean that many postdocs need to constantly struggle to stay afloat.

Precarious working situations might also partly explain why some of the STEM PhD holders we interviewed had left academia for more secure working conditions and better pay in the private sector (Bataille, Le Feuvre, \& Kradolfer, 2017). Throughout our interviews, higher salaries were never mentioned as the sole reason for a STEM researcher to leave academia, but they often seemed to function as that last push towards a career change. Those who stay in academia seem only too aware of the fact that they could be financially much better off elsewhere. As a male assistant professor in STEM put it: 'This is the worst paid job I could get with my education. Everything else I could do would be better paid.' A female former assistant professor reiterated this point when she said that she is 'concerned for the future of [her former] department because it's coming up against market forces'. She pointed out that: 'people teach there out of the goodness of their hearts'. She viewed her: 'two years at the university as my obligation to society, like, "I've done my volunteer work for two years, now get off my back!'” In other words, the pay gap between the private sector and the academy is so vast that some STEM academics think of their academic job as a type of charity work.

To some extent, SSH PhDs have the opposite experience to those of their STEM counterparts. With few opportunities of obtaining a postdoc or a research position within the University, opportunities outside academia are also rare. Within the University, SSH PhDs often have to provide for themselves as sessional teachers or adjuncts, which are temporary and poorly paid positions with few legal rights and benefits, making them unsustainable options for PhD holders in the long term. As a female adjunct pointed out:

Sessional teachers have no rights within the University ... [Even] if you have a $\mathrm{PhD}$, the university itself decides how sessional teachers are paid [because] they're not allowed a working contract at the university.

But while sessional teaching at the university is temporary, badly paid and insecure, one might still be tempted to fantasize that such hard work would eventually be rewarded with a permanent position. This, however, is not the case. As a key player in SSH points out, sessional teachers 'want to work in research and want to get a position, which is difficult because we know that there will not be any job openings'. In this way, sessional teaching positions are perhaps best described as continuous, self-perpetuating ruts in the world of academia. In STEM, the sessional teaching positions are mostly occupied by people who already have a non-academic job and, according to a key player, they can expect to be paid 15-25 per cent above the formal rate.

\subsection{Assistant professor: A position contingent on excellence - and support}

The PhD graduates who obtain an assistant professorship within the University are not immune to precarious working situations from the pressure of publishing in international journals and obtaining research grants. This is reflected in the following statement by a former male adjunct: '[Even if] the way they treat sessional teachers around here is quite despicable, things don't get much better once you become a lecturer.' This pressure on academics can be reflected in the agreement between the University and the Ministry of Education. Academics are responsible for the financial prosperity of their faculty:

Research funding is distributed between the academic schools and faculties in accordance with the points that each unit gains. Thus, low levels of research activity are no longer seen as the personal problem of the 
academic staff member in question [...] since low levels of research also reduce the income of the faculty in question. (Agreement on Teaching and Research, 2012-2016, Appendix 1, 34)

As seen earlier, this approach ignores the systematic gender bias within the University that can be reflected in the STEM-focused evaluation of academic work and a highly gendered support system.

\subsection{A highly gendered and STEM-focused evaluation system}

Assistant professors need to accumulate a certain number of major points in order to stand any chance of promotion to a permanent position at the University (Regulation no. 263/2010). In 2013, STEM academics received, on average, 27 per cent more points than SSH academics. However, the average number of major points per academic staff member was 60 per cent higher in STEM than in SSH (University of Iceland, n.d.-d). This might indicate that the academics in STEM are more active researchers than in SSH, however, as argued previously, the evaluation system tends to be based on STEM-focused performance measurements and systematically undervalues teaching and related activities (Steinpórsdóttir et al., 2017). Clearly, reaching the required number of major points will prove to be more difficult for an assistant professor in SSH than in STEM. A female assistant professor in SSH is worried that she will lose her position because her points are not seen as 'noteworthy' enough:

I just don't think l've been doing enough. I've got plenty of points, but not interesting enough points [major points] ... because l've always been around here writing in the national context and done work for the ministry [...] So, as I said, you don't really get anything for that.

She is stuck in a rut with not enough major points. Even though she has been working full-time and to the best of her ability, her research work simply does not count as much as research done in an international, STEM-focused context.

In 2013, the full-time teacher to student ratio was 1:43 in SSH as compared to 1:21 in STEM (University of Iceland, n.d.-e). In SSH, the high student-teacher ratio affects the working conditions of all the academic staff, especially the newcomers. As one key player in SSH noted: 'Because there is a great need for these newly recruited lecturers, it always results in them getting buried in teaching.' All the SSH academics interviewed had experienced heavy teaching workloads. In STEM, however, few newcomers experience teaching overload and have a more balanced research and teaching workload. For academics with extensive teaching responsibilities, it can be difficult to find time to do research and to collect the appropriate points for career advancement. A male SSH assistant professor reflects on how this impacts his career perspectives at the University:

How am I supposed to do the research needed to get the associate professorship and the tenured position, because teaching is eating up my time? I have 14 research projects, some big, some small, at least four articles based on my thesis, I am seeing all of them sort of being delayed or destroyed because of too much teaching.

In the interviews, key players in STEM revealed that the school acknowledges the heavy workload of teaching by giving their newly hired assistant professors a teaching discount and funding to support them on their quest for acquiring the required number of major points. Our key players in SSH realize this and believe that the school should better support the assistant professors in reaching their performance targets, as would seem to be the case in STEM. However, the SSH school lacks the budget required to provide such support, notably due to the distribution of public funding within the University that provides STEM schools with 60-100 per cent more funding per full-time equivalent student than in SSH (Steinpórsdóttir et al., 2017).

\section{5 | Research funding: A condition for staying in the game}

In a context of global competition, the excellence of academic institutions is measured by their ability to capture resources (Paradeise \& Thoenig, 2015). This is in line with the performance measurements utilized to distribute public 
funding to the schools within the University. The schools receive matching funds for their success: 60 per cent of the value of research funding received through internationally competitive calls, 35 per cent for funding from nationally competitive sources and 20 per cent for other sources of research funding (Steinpórsdóttir et al., 2017). Under such a system, all academics, including assistant professors, are under intense pressure to apply for external research funding (University of Iceland, 2006, 2011, n.d.-c). However, data on the funding received at the University through competitive research programmes at international, national and internal (i.e., University) levels suggests that assistant professors, especially from SSH, have little chance of obtaining research funds. Information on international competitive funding is rather scarce, but data on grants received from the European Union's Seventh Framework Programme for the years 2008-2014 reveals that academics from STEM were significantly more successful in obtaining European funding than those from SSH (7.25 times more successful, in fact) (University of Iceland, 2014). The discipline gap was lower for nationally funded projects (four successful applicants in STEM for every project received in SSH in 2013) and was again smaller for internal funding (three STEM projects to every SSH one funded (The Icelandic Centre for Research, n.d.; University of Iceland, n.d.-a)). In addition, men were between three (national) and four (internal) times more likely to receive funding than their female counterparts (The Icelandic Centre for Research, $\mathrm{n}$. d.; University of Iceland, n.d.-a). Furthermore, academics from SSH departments are less likely to apply for internal funding than those from STEM, and women are always less likely to apply than men (University of Iceland, n.d.-a). Most of the national and internal grants were allocated to the highest ranking academics, full professors and research scientists (80-90 per cent). Assistant professors only received internal grants, which are significantly less generous than external funded projects (The Icelandic Centre for Research, n.d.; University of Iceland, n.d.-a).

When they receive funding of any kind, assistant professors can hire PhD students, postdocs or assistants and buy themselves out of teaching, which increases the likelihood of more publications and, thus, points (University of Iceland, n.d.-g). However, the previous research activities of the applicant (measured by their previously accumulated points) and the type of academic position occupied also determine the chances of securing research funding (Regulation no. 659/2009). Due to this, the lion's share of funding usually goes to the highest ranking academics in the STEM field, most of whom are men. Even within STEM fields, the research funding process is gendered. As a female STEM assistant professor pointed out: 'When you get to the higher positions, it's about who can get projects, get funding and so on and for some reason it tends to be men.'

Moreover, some of our interviewees shed light on another reason why assistant professors in SSH might have a difficult time securing funding. This is related to different perceptions of scientific objectivity in STEM and SSH fields. Unlike our STEM interviewees, quite a few SSH early career academics spoke of the difficulties they had experienced in obtaining funding because of the perceived 'political' nature of their work. Thus, the natural sciences are often perceived as being focused on establishing natural laws, which works through experimentation and causal analysis, while the social sciences are perceived as being rooted in interpretive examination, which is perceived as potentially politically motivated, or biased (Reiss \& Sprenger, 2017). A male social scientist pointed out that: '[as a researcher] in Iceland you have to avoid talking about your political ideas publicly, because that cuts your funding'. He further developed this point as follows:

In Iceland [...] a tremendous amount of research is funded through government channels, often through arbitrary decisions made by ministers in government and so on. And you have to be able to sort of adapt, to a certain extent, to their views and interests, otherwise you're not going to get any of that funding.

\section{8 | CONCLUDING REMARKS}

By scrutinizing the processes and procedures adopted at the University through the lens of gender budgeting, we found that the system privileges male-dominated and culturally masculine fields and acts to the disadvantage of early career academics. Women are more likely to occupy the most precarious academic positions, while men dominate the 
more senior and secure academic positions. In addition, academics in the more feminized fields are in more precarious positions than academics in male-dominated and culturally masculine fields. This is reflected in the managerial mechanisms of the University that ensure that STEM is able to provide better employment and working conditions for academics at all levels of the early academic career trajectory than SSH.

Gendered forms of precarity start at the level of the PhD programmes. Not all PhD candidates are funded to carry out their research and this has potentially wide-ranging consequences regarding salaries and benefits (Kramer et al., 2014; Leslie \& Gappa, 2002; Valadez \& Anthony, 2001). These inequalities are structurally gendered, since men are more likely to have secure funding or a salary for the duration of their $\mathrm{PhD}$ programme than their female counterparts. At the University there is a clear research funding gap, with male-dominated fields receiving more funding per student than the more feminized fields. This not only impacts the financial situation of the PhD candidates, but also the duration of their doctoral studies. Moreover, in both fields the duration of PhD studies is shorter for men than for women.

The University is committed to increasing the size of what Ivancheva (2015) has called an 'army of workers' (p. 39), in the form of $\mathrm{PhD}$ candidates, without sufficient consideration for the consequences of this policy for the people concerned. We see a gendered aspect to these inflationary practices, given that PhD holders from the male-dominated STEM fields have better career opportunities than the SSH PhD holders, both inside and outside academia. The STEM PhD graduates that continue as postdocs experience their positions as precarious. However, the interviews reveal that they have the opportunity to leave and take a job in the private sector where they will receive higher salaries and more secure working conditions. The experience of the SSH PhD holders is quite different: after obtaining a doctorate, there are few opportunities for secure employment, either inside or outside academia. The PhD holders that decide to pursue a career at the University often have to rely on insecure and badly paid jobs, such as sessional teaching.

Assistant professor positions are not immune from precarious working conditions. Both in STEM and SSH, the adoption of new managerial tools in order to maximize efficiency and productivity puts immense pressure on academics to publish and to secure external funding (Barry et al., 2012; Butler \& Spoelstra, 2014; Chandler et al., 2004; Farnham, 1999; Gouthro, 2002; Lynch, 2006; O'Connor, 2014; Rothe et al., 2008; Välimaa, 2012). The performance indicators encourage a self-monitoring process (Deem et al., 2007), making early career stage academics not only responsible for their own future within the University and their own wellbeing (Keisu \& Carbin, 2014), but also for the financial livelihood of their own faculty. These academics are made to bear this responsibility, even though they have little to no control over wider, gendered processes (Berg et al., 2016). This is evident in a system that is based on STEM-focused research indicators, ignores unfavourable student-teacher ratios and the teaching workload in SSH, and overlooks the fact that there are many more potential funding opportunities in STEM fields. This increases the growing precariousness among academics and can partly explain why some STEM PhD holders leave academia, an opportunity that is rare for academics in the more feminized SSH. Owing to the fact the gender-biased evaluation system is directly connected to the distribution of funding within the institution, the STEM field is able to provide support to those who stay by minimizing teaching workloads and providing internal research support.

By over-rewarding academics in male-dominated and culturally masculine fields and by plunging early career academics from more feminized fields into a competitive and precarious environment, new managerialism practices at academic institutions clearly serve to maintain and reinforce existing gender inequalities. By following the money in this particular institution, we have revealed a gendered structural bias that lurks behind the apparent neutrality and objectivity of academic evaluation procedures. We believe that the example of this particular academic institution can provide a deeper understanding of the potential consequences of new managerialism in academia more generally. However, further and more international comparative research into the gendered nature of new managerialism in higher education is needed. Gender budgeting provides a potentially insightful tool for undertaking such comparative studies, providing that institutions are as transparent in their evaluation and funding criteria as is the case of the University studied here. 


\section{DECLARATION OF CONFLICTING INTEREST}

The authors declared no potential conflicts of interest with respect to the authorship and/or publication of this article.

\section{ENDNOTE}

${ }^{1}$ GARCIA: Gendering the Academy and Research: Combating Career Instability and Asymmetries, FP7/2007-2013, grant agreement $n^{\circ} 611737$.

\section{ORCID}

Finnborg S. Steinpórsdóttir (10 http://orcid.org/0000-0001-9581-0310

Thomas Brorsen Smidt (1) http://orcid.org/0000-0002-6118-3280

Gyða M. Pétursdóttir (1) http://orcid.org/0000-0002-7678-2008

porgerður Einarsdóttir (1) http://orcid.org/0000-0001-8906-0760

Nicky Le Feuvre (10) http://orcid.org/0000-0002-8107-9341

\section{REFERENCES}

Acker, J. (1992). From sex roles to gendered institutions. Contemporary Sociology, 21(5), 565-569.

Acker, J. (2006). 'Inequality regimes: Gender, class, and race in organizations'. Gender \& Society, 20, 441-464.

Adamowicz, C. (2007). On adjunct labor and community colleges: Exploiting part-timers damages everyone at an institution. Academe, 93, 24-27.

Addabbo, T., Gunluk-Senesen, G., \& O'Hagan, A. (2015). Gender budgeting: Insights from current methodologies and experiences in Europe. Politica Economica/Journal of Economic Policy, XXXI(2), 125-134.

Agreement on teaching and research between University of Iceland and the Ministry of Education, Research and Culture. (2012-2016). Appendix 1 (in Icelandic).

Bacchi, C. (2009). Analysing policy. Frenchs Forest, Australia: Pearson Higher Education.

Bacchi, C. (2012). Why study problematizations? Making politics visible. Open Journal of Political Science, 2(1), 1-8.

Barry, J., Berg, E., \& Chandler, J. (2012). Movement and coalition in contention: Gender, management and academe in England and Sweden. Gender, Work and Organization, 19(1), 52-70.

Bataille, P., Le Feuvre, N., \& Kradolfer, S. (2017). Should I stay or should I go? The effects of precariousness on the gendered career aspirations of postdocs in Switzerland. European Educational Research Journal, 16(2-3), 313-331.

Berg, L. D., Huijbens, E. H., \& Larsen, H. G. (2016). Producing anxiety in the neoliberal university. The Canadian Geographer/Le géographe canadien, 60(2), 168-180.

Borum, F., \& Hansen, H. F. (2000). The local construction and enactment of standards for research evaluation: The case of the Copenhagen Business School. Evaluation, 6(3), 88-104.

Butler, N., \& Spoelstra, S. (2014). The regime of excellence and the erosion of ethos in critical management studies. British Journal of Management, 25, 538-550.

Chandler, J., Barry, J., \& Berg, E. (2004). Reforming managerialism? Gender and the navigation of change in higher education in Sweden and England. In R. Thomas, A. J. Mills, \& J. H. Mills (Eds.), Identity politics at work: Resisting gender, gendering resistance (pp. 123-140). London, UK: Routledge.

Deem, R., \& Brehony, K. J. (2007). Management as ideology: The case of 'new managerialism' in higher education. Oxford Review of Education, 31(2), 217-235.

Deem, R., Hillyard, S., \& Reed, M. (2007). Knowledge, higher education, and the new managerialism. New York, NY: Oxford University Press.

Donoghue, F. (2008). The last professors: The corporate university and the fate of the humanities. New York, NY: Fordham University Press.

Duguay, C. R., Laundry, S., \& Pasin, F. (1997). From mass production to flexible/agile production. International Journal of Operations \& Production Management, 17, 1183-1195.

Einarsdóttir, D. (1998). Kynjamunur í vinnumatskerfi háskólakennara [Gender inequality in the university incentive system]. Fréttablað Háskóla Íslands, 32-33. 
Einarsdóttir, P., Pétursdóttir, G. M., Steinpórsdóttir, F. S., Gústafsdóttir, G., Heijstra, T. M., \& Brorsen Smidt, T. (2015). Iceland. In C. Herschberg, Y. Benschop \& M. van den Brink (Eds.), Constructing excellence: the gap between formal and actual selection criteria for early career academics, GARCIA working papers no. 2. (pp. 149-178), Italy: University of Trento.

Elson, D. (1999). Gender budget initiative: Background papers. London, UK: Commonwealth Secretariat.

European Commission. Directorate-General for Research and Innovation (2016). She figures 2015. Luxembourg: Publications Office.

Evaluation System for Public Higher Education Institutions. (2013). Retrieved from http://www.hi.is/sites/default/files/ admin/meginmal/skjol/evaluation_system_for_public_higher_education_institutions.pdf (in Icelandic).

Farnham, P. (1999). Managing academic staff in changing university system: International trends and comparisons. Milton Keynes, UK: Open University Press.

Francis, B., Archer, L., Moote, J., DeWitt, J., MacLeod, E., \& Yeomans, L. (2017). The construction of physics as a quintessentially masculine subject: Young people's perceptions of gender issues in access to physics. Sex Roles, 76(3-4), 156-174.

Fudge, J., \& Owens, R. (2006). Precarious work, women, and the new economy: The challenge to legal norms. Oxford, UK: Hart.

Fusulier, B., del Rio Carral, M., \& Murgia, A. (2013). Juggling work and life in academia: Focus on early stages of Belgian and Italian scientific careers. SASE 25th Annual Conference, University of Milan.

Gill, R. (2009). Breaking the silence: Hidden injuries of the neoliberal university. In R. Ryan-Flood, \& R. Gill (Eds.), Secrecy and silence in the research process: Feminist reflections (pp. 228-244). London, UK: Routledge.

Ginsberg, B. (2011). The fall of the faculty: The rise of the all-administrative university and why it matters. New York, NY: Oxford University Press.

Gouthro, P. A. (2002). 'What counts? Examining academic values and women's life experiences from a critical feminist perspective'. CJSAE/RCÉÉA, 16(1): 1-10.

Heijstra, T. M., Einarsdóttir, D., Pétursdóttir, G. M., \& Steinpórsdóttir, F. S. (2017). Testing the concept of academic housework in a European setting: Part of academic career-making or gendered barrier to the top? European Educational Research Journal, 16, 200-214.

Heijstra, T. M., Steinpórsdóttir, F. S., \& Einarsdóttir, P. (2017). Academic career making and the double-edged role of academic housework. Gender and Education, 29, 764-780.

Ivancheva, M. P. (2015). The age of precarity and the new challenges to the academic profession. Studia Universitatis BabesBolyai - Studia Europaea, 60(1), 39-48.

Jóhannesson, I. Á. (2013). Excellence, innovation and academic freedom in university policy in Iceland. Stjórnmál og stjórnsýsla, 9(1), 79-99.

Jongbloed, B. W. A. (2012). Academic pay in Western Europe. International Higher Education, 2012(68), 5-6.

Kalleberg, A. L. (2009). Precarious work, insecure workers: Employment relations in transition. American Sociological Review, 74, 1-22.

Keisu, B. I., \& Carbin, M. (2014). Administrators or critical cynics? A study of gender equality workers in Swedish higher education. NORA - Nordic Journal of Feminist and Gender Research, 22(3), 204-218.

Kezar, A., Maxey, D., \& Eaton, J. (2014). An examination of the changing faculty: Ensuring institutional quality and achieving desired student learning outcomes. Institute for Research and Study of Accreditation and Quality Assurance. Washington, DC. Retrieved from https://www.chea.org/userfiles/Occasional\%20Papers/Examination_Changing_Faculty_2013.pdf

Klentzin, J. C., \& Bucci, D. T. (2012). Part-time faculty and the academic library: A Case Study. The Journal of Academic Librarianship, 38, 101-107.

Knobloch-Westerwick, S., Glynn, C. J., \& Huge, M. (2013). The Matilda Effect in science communication an experiment on gender bias in publication quality perceptions and collaboration interest. Science Communication, 35, 603-625.

Kramer, A. L., Gloeckner, G. W., \& Jacoby, D. (2014). Roads scholars: Part-time faculty job satisfaction in community colleges. Community College Journal of Research and Practice, 38, 287-299.

Larner, W. (2000). Neo-liberalism policy, ideology, governmentality. Studies in Political Economy, 63(1), 5-25.

Leslie, D. W., \& Gappa, J. M. (2002). Part-time faculty: Competent and committed. New Directions for Community Colleges, 2002(118), 59-68.

Levecque, K., Anseel, F., Beuckelaer, A. D., Heyden, J. V. d., \& Gisle, L. (2017). Work organization and mental health problems in PhD students. Research Policy, 46(4), 868-879.

Lipton, B. (2015). Gender and precarity: A response to Simon During. Australian Humanities Review, 58(2015), 63-69.

Lynch, K. (2006). Neo-liberalism and marketisation: The implications for higher education. European Educational Research Journal, 5(1), 1-17. 
Lynch, K. (2010). Carelessness: A hidden doxa of higher education. Arts and Humanities in Higher Education, 9(1), 54-67.

Lynch, K. (2014). New managerialism: The impact on education. Concept: The Journal of Contemporary Community Education Practice Theory, 5(3), 1-11.

Marginson, S., \& Van der Wende, M. (2007). To rank or to be ranked: The impact of global rankings in higher education. Journal of Studies in International Education, 11(3-4), 306-329.

Newfield, C. (2008). Unmaking the Public University: The Forty-Year Assault on the Middle Class. Cambridge: Havard University Press.

O'Connor, P. (2014). Management and Gender in Higher Education. Manchester: Manchester University Press.

O'Hagan, A. (2016). Challenging the norms: Gender budgeting as feminist policy change. In J. Campbell, \& M. Gillespie (Eds.), Feminist economics and public policy: Reflections on the work and impact of Ailsa McKay (pp. 41-49). Abingdon, UK: Routledge.

Olssen, M., \& Peters, M. A. (2010). Neoliberalism, higher education and the knowledge economy: From the free market to knowledge capitalism. Journal of Education Policy, 20(3), 313-345.

Paradeise, C., \& Thoenig, J. (2015). In search of academic quality. Basingstoke, UK: Palgrave Macmillan.

Parker, M., \& Jary, D. (1995). The McUniversity: Organization, management and academic subjectivity. Organization, 2(2), 319-338.

Pronin, E., Steele, C. M., \& Ross, L. (2004). Identity bifurcation in response to stereotype threat: Women and mathematics. Journal of Experimental Social Psychology, 40(2), 152-168.

Quinn, S. (2009). Gender budgeting: Practical implementation. Strasbourg, France: Council of Europe, Directorate General of Human Rights and Legal Affairs.

Regulation of the University of Iceland no. 659/2010.

Regulation on the promotion and permanent appointment of academic staff at the University of Iceland no. 263/2010.

Reiss, J., \& Sprenger, J. (2017). Scientific objectivity. In E. N. Zalta (Ed.), The Stanford encyclopedia of philosophy ((spring (spring 2017 ed.). Stanford, CA: Stanford University. Retrieved from https://plato.stanford.edu/archives/spr2017/entries/scientific-objectivity/

Rossiter, M. W. (1993). The Matthew Matilda effect in science. Social Studies of Science, 23(2), 325-341.

Rothe, A., Erbe, B., Fröhlich, W., Klatzer, E., Lapniewska, Z., Mayrhofer, M., ... Debski, M. (2008). Gender Budgeting as a Management Strategy for Gender Equality at Universities: Concluding Project Report Frauenakademie München (ISBN-13:978-3-937120-09-6).

Schiebinger, L. (1999). Has feminism changed science? . Cambridge, MA: Harvard University Press.

Schuster, J. H. (2003). The faculty makeover: What does it mean for students? New Directions for Higher Education, 2003(123), 15-22.

Schuster, J. H., \& Finkelstein, M. J. (2006). The American faculty: The restructuring of academic work and careers. Baltimore, MD: JHU Press.

Sharp, R., \& Broomhill, R. (2002). Budgeting for equality: The Australian experience. Feminist Economics, 8(1), 25-47.

Slaughter, S., \& Rhoades, G. (2004). Academic capitalism and the new economy: Markets, state, and higher education. Chicago, IL: JHU Press.

Steinpórsdóttir, F. S., Heijstra, T. M., Einarsdóttir, D. \& Pétursdóttir, G. M. (Eds.) (2016). Gender budgeting in academia, GARCIA working papers no. 8. Italy: University of Trento.

Steinpórsdóttir, F. S., Heijstra, T. M., \& Einarsdóttir, T. (2017). The Making of the 'Excellent' University: A Drawback for Gender Equality. Ephemera. Theory \& Politics in Organization, 17, 557-582.

Svensson, P., Spoelstra, S., Pedersen, M., \& Schreven, S. (2010). The excellent institution (editorial). Ephemera: Theory \& Politics in Organization, 10(1), 1-6.

The Icelandic Centre for Research. (n.d.). Úthlutanir úr rannsóknar- og nýsköpunarsjóðum [Allocation from research and innovation funds]. Retrieved from http://rannis.rhi.hi.is/AllocatedFunds/all.php

Torres, C. A., \& Schugurensky, D. (2002). The political economy of higher education in the era of neoliberal globalization: Latin America in comparative perspective. Journal of Higher Education, 43(4), 429-455.

Treanor, P. (2005, December 2). Neoliberalism: Origins, theory, definition. Retrieved from http://web.inter.nl.net/users/Paul. Treanor/neoliberalism.html

University of Iceland. (2006). Policy of the University of Iceland 2006-2011. Retrieved from http://english.hi.is/files/bryndjo/ policy_of_the_university_of_iceland_2006.pdf 
University of Iceland. (2011). Policy of the University of Iceland 2011-2016. Retrieved from http://english.hi.is/files/ afmaeliforsida/policy_2011-2016.pdf

University of Iceland. (2014). Verkefni innan HÍ sem hafa hlotið styrk úr 7RÁ [Projects within UI that have received FP7 funding]. Retrieved from http://www.hi.is/sites/default/files/admin/meginmal/skjol/Yfirlit\%20verkefna\%2022.9.2014.pdf

University of Iceland. (2016). Strategy of the University of Iceland 2016-2021. Retrieved from http://english.hi.is/files/ bryndjo/baeklingar/hi21_brochure_ens-01-web.pdf

University of Iceland. (n.d.-a). Statistical information on grantees from internal funds of The University of Iceland in 2013. Retrieved from the Division of Science and Innovation, University of Iceland.

University of Iceland. (n.d.-b). Brautskráðir doktorar frá Háskóla Íslands 2010-2013 [Graduated PhD candidates from University of Iceland in 2010-2013]. Retrieved from the Graduate School, University of Iceland.

University of Iceland. (n.d.-c). Evaluation system for public universities. Retrieved from http://www.hi.is/sites/default/files/ oldSchool/evaluation_system_english.pdf

University of Iceland. (n.d.-d). Rannsóknarstig 2013 [Research points 2013]. Retrieved from http://www.hi.is/adalvefur/ rannsoknastig_fra_1999

University of Iceland. (n.d.-e). HÍ í tölum [Statistical information on UI]. Retrieved from http://www.hi.is/adalvefur/hi_i_ tolum

University of Iceland. (n.d.-f). Styrkpegar og tölfræði [Grantees and statistics]. Retrieved from http://sjodir.hi.is/styrkthegar_ og_tolfraedi

University of Iceland. (n.d.-g). Vinnureglur við úthlutun [Allocation working methods]. Retrieved from http://sjodir.hi.is/ reglur_rannsoknasjods

Valadez, J. R., \& Anthony, J. S. (2001). Job satisfaction and commitment of two-year college part-time faculty. Community College Journal of Research and Practice, 25, 97-108.

Välimaa, J. (2012). 'The Corporatizaion of National Universities in Finland'. In B. Pusser, K. Kemper, S. Marginson \& I. Ordorika (Eds.), Universities and the Public Sphere: Knowledge Creation and State Building in the Era of Globalization (pp. XX-XX). New York: Routledge.

Van den Brink, M., \& Benschop, Y. (2011). Gender practices in the construction of academic excellence: Sheep with five legs. Organization, 19, 507-524.

Walsh, S. N. (2013). Counterrevolution and repression in the politics of education: At the midnight of dissent. Lanham, MD: Lexington Books.

Ward, S. C. (2012). Neoliberalism and the Global Restructuring of Knowledge and Education. New York: Routledge.

Finnborg Salome Steinbórsdóttir is a postdoctoral researcher and sessional teacher in Gender Studies at the University of Iceland. Her research interests are gender budgeting, gender relations and organizational cultures, and gender-based violence. She is currently working on the H2020-funded project ACT Communities of Practice for Accelerating Gender Equality and Institutional Change in Research and Innovation across Europe.

Thomas Brorsen Smidt is a PhD student in Gender Studies at the University of Iceland. Apart from topics relating to gender in higher education, his research interests also span the fields of masculinity and queer studies as well as the politics of sexuality, pornography and sexual harassment.

Gyða Margrét Pétursdóttir is an associate professor in Gender Studies at the Faculty of Political Science, University of Iceland. She completed her PhD in Gender Studies from the University of Iceland in 2009. Her research areas focus on gender relations in a broad sense focusing among others on masculinities, femininities, organizational culture, work \& family life and gender-based violence. Pétursdóttir has participated in various research networks and EU-funded research projects.

Porgerður J. Einarsdóttir is Full Professor of Gender Studies at the University of Iceland. Her research areas cover a broad range of issues from feminist theory and equality policies to labour market issues, masculinities, gender and academia and transgender issues. She recently coordinated the Icelandic contribution to an FP7 
European research project on precariousness in early academic careers (www.garciaproject.eu) and is currently working on the H2020-funded project ACT Communities of Practice for Accelerating Gender Equality and Institutional Change in Research and Innovation across Europe.

Nicky Le Feuvre is Full Professor of Sociology at the University of Lausanne, where she is Vice-Dean for gender equality and early academic careers at the Faculty of Social and Political Sciences. She has researched extensively on the feminization of higher-level occupations from a cross-national comparative and life-course perspective. She is currently director of the Gender \& Occupations sub-project of the NCCR LIVES (www.lives-nccr.ch). She recently coordinated the Swiss contribution to an FP7 European research project on precariousness in early academic careers (www.garciaproject.eu) and is currently working on an SNSF-funded project on the feminization of the legal profession in Europe (https://wp.unil.ch/legalpro/).

How to cite this article: Steinbórsdóttir FS, Brorsen Smidt T, Pétursdóttir GM, Einarsdóttir P, Le Feuvre N. New managerialism in the academy: Gender bias and precarity. Gender Work Organ. 2018;1-16. https://doi. org/10.1111/gwao.12286 